\title{
THE TORNIO LAYERED INTRUSION - A RECENTLY DISCOVERED INTRUSION WITH CHROMITITE HORIZONS IN NORTHERN FINLAND
}

\author{
KRISTER SÖDERHOLM and OSMO INKINEN
}

\begin{abstract}
SÖDERHOLM, KRISTER and INKINEN, OSMO 1982: The Tornio layered intrusion - a recently discovered intrusion with chromitite horizons in Northern Finland. Bull. Geol. Soc. Finland 54, 1-2, $15-24$.
\end{abstract}

In the 1960's chromite boulders were found in the area between the Kemi chromium mine and the town of Tornio. In 1979 after many years of prospecting a layered intrusion with thin chromitite layers was found northeast of the town of Tornio.

The stratified sill-like intrusion is situated between the Presvecokarelian basement complex and the Peräpohja schist formation. The age of the intrusion is very likely the same as that of the Kemi and Penikat intrusions, that is $2440 \mathrm{Ma}$. The rocks both below and immediately above these intrusions are older than $2440 \mathrm{Ma}$. The length of the intrusion is at least $6 \mathrm{~km}$ and it extends into Sweden.

Several thin chromitite layers have been intersected by drilling, all in the ultramafic unit. The $\mathrm{Cr}_{2} \mathrm{O}_{3}$ content of the chromitite layers varies between 26 and $32 \%$, the $\mathrm{FeO}_{\text {tot }}$ content between 22 and $28 \%$ and the $\mathrm{Cr} / \mathrm{Fe}$ ratio between 0.9 and 1.2 . The chromites are Fe-rich and $\mathrm{Mg}$-poor averaging $43 \% \mathrm{Cr}_{2} \mathrm{O}_{3}$.

The chromite deposit of the Tornio intrusion, like those of the Kemi and Penikat intrusions, is of the stratiform type. The Tornio and Penikat intrusions resemble each other as do the compositions of their chromites.

Krister Söderholm, Outokumpu Oy. Kemi mine, PL 8, SF-94101 Kemi 10, Finland.

Osmo Inkinen, Outokumpu Oy, Mining Technology Group, SF-83500 Outokumpu, Finland.

\section{Introduction}

When the Exploration Division of Outokumpu Oy started follow-up studies on the Elijärvi chromite deposit at Kemi in 1960 activities were extended to include the environment. As a result, several chromitite floats were discovered in 1962-1966 that, with reference to the glacial transport direction, were located on the wrong side of the Elijärvi de- posit in the terrain between Tornio and Elijärvi. This suggested that a new chromite occurence could be found at the apex of the boulder train north of Alaraumo.

Geological mapping, Quaternary geological studies, geochemical surveys and geophysical reconnaissance measurements were undertaken during a period of several years 


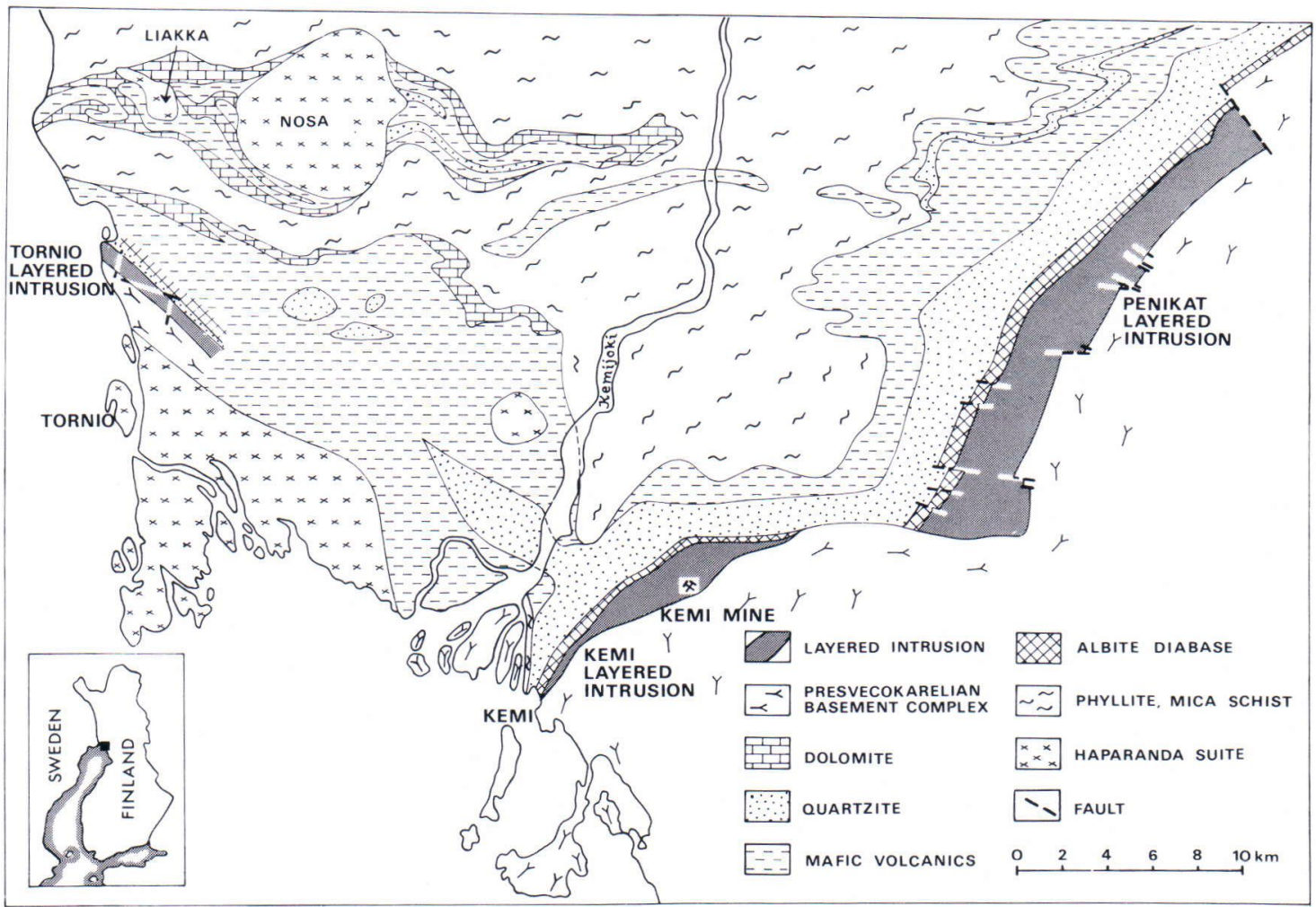

Fig. 1. The location of the Tornio, Kemi and Penikat layered intrusions between the Peräpohja schist formation and the Presvecokarelian basement complex. Modified after V. Perttunen 1971-1975.

in the area between Elijärvi, Tornio and Karunki (Inkinen 1979). Although the source of the chromitite floats could not be located in these studies, the occurence could be restricted to a fairly small area NE of Tornio. This area was submitted to ground magnetic and gravimetric surveys in 1978 and 1979. Twelve diamond holes drilled in the area in 1979-1980 resulted in the discovery of a layered intrusion with narrow chromitite layers NE of Tornio, and which in this context is called the Tornio layered intrusion.

\section{General Geology}

The Tornio layered intrusion is located NE of the town of Tornio between Alavojakkala and Yliraumo (Fig. 1). The area is of poor outcrop and the layered intrusion is exposed only in one outcrop on Oravainen, an island close to the Swedish border. The drilling shows that the intrusion is slablike in shape, at least $6 \mathrm{~km}$ long in Finnish territory and extending into Swedish territory (Claesson, Geological Survey of Sweden, oral communication 1981).

South of the Tornio layered intrusion there are mica and hornblende gneisses that we interpret as part of the Presvecokarelian basement complex. The complex also includes granitic portions. Some of the silicic plutonic rocks may belong to the Haparanda suite, whose members predominate south of the area and which include plutonic rocks varying in composition from hornblendite to granite (Brotzen 1973).

Like the Kemi and Penikat layered intrusions, the Tornio intrusion is located between 
the Peräpohja schists, which are considered as Karelian, and the Presvecokarelian basement complex.

The NE contact of the layered intrusion has not been intersected by diamond drilling. Holes drilled about $1.5 \mathrm{~km}$ north of the intrusion, however, demonstrate the existence of quartzites and albite diabases between the intrusion and the greenstone area. The Kemi and Penikat layered intrusions are overlain by a shallow conglomerate layer with granitic pebbles derived from the basement complex. Northwest of the Kemi intrusion, the conglomerate is overlain alternately by mafic volcanics and silicic metasediments and only after them by albite diabases.

The NW portion of the Tornio layered intrusion is crosscut by a metadiabase dyke trending c. N $60 \mathrm{~W}$. On account of its magnetite content, it is clearly visible on magnetic maps, as are the albite diabases overlying the layered intrusion. The magnetic maps also suggest that the area is intersected by faults and shears trending N 05-010 E and N 60-70 W.

There are no radiometric datings for the rocks of the area. The age determinations by the Geological Survey of Finland, however, indicate that the Presvecokarelian basement complex is 2700-2800 Ma old. The zircon age of the Kemi layered intrusion is about 2440 Ma (Kouvo 1977; Patchett et al., in press); the same age was obtained from the whole rock total lead isochron (Manhes et al., 1980). The layered intrusions at Penikat (Kouvo 1977), Koitelainen (Mutanen 1979) Porttivaara and Näränkä (Alapieti 1982) are of the same age, and it is highly probable that the Tornio layered intrusion is also of the same age. The diabase dykes cutting the Kemi layered intrusion are $2200 \mathrm{Ma}$ old (Geological Survey of Finland 1981). The granite pebbles in the conglomerate overlying the Kemi and Penikat layered intrusions are 2600 $\mathrm{Ma}$ in age (Perttunen 1980). Stratigraphically the conglomerate and overlying schists belong to the Lower Jatulian Group (Perttunen 1980) and are older than the layered intrusions. Hence, the layered intrusions are sandwiched between rocks that are older than they. It can also be assumed that all the portions of the layered intrusions have been preserved and that the upper portions have not been eroded.

The rocks of the Haparanda suite show a $1880 \mathrm{Ma}$ Rb-Sr isochron (Welin et al., 1970) and 1890 Ma zircon ages (Kaakamo diorite, Geological Survey of Finland 1977; Liakka gabbro, Geological Survey of Finland 1981). Brotzen, however, has obtained considerably higher Rb-Sr ages for them. The Geological Survey of Finland (1981) has also reported higher Zr ages for the Nosa granodiorite (see Fig. 1). Further research is thus needed to settle the issue. Nevertheless, we feel that at least some of the rocks of the Haparanda suite, e.g. the Nosa granodiorite, are of the remobilised Archean basement complex.

\section{The Tornio layered intrusion}

The Tornio layered intrusion was emplaced as a sill between the Archean basement complex and slightly younger schists. The intrusion, which was originally subhorizontal, dips $65^{\circ}-75^{\circ} \mathrm{NE}$, i.e. as steeply as the Kemi intrusion. Its strike length in Finnish territory is at least $6 \mathrm{~km}$, and its width not less than 0.4 to $0.5 \mathrm{~km}$.

The Tornio layered intrusion can be subdivided into a lower ultramafic unit and an upper mafic unit (Fig. 2). The ultramafic lower unit, which is from 80 to $215 \mathrm{~m}$ thick, can be further subdivided into three layers (I, II, III). The mafic upper unit is over $200 \mathrm{~m}$ thick and is composed of two layers (IV and V). The layers often grade into one other, in places, however, the boundaries are sharp.

The layering is well-developed and manifests itself best as a frequent alternation of 

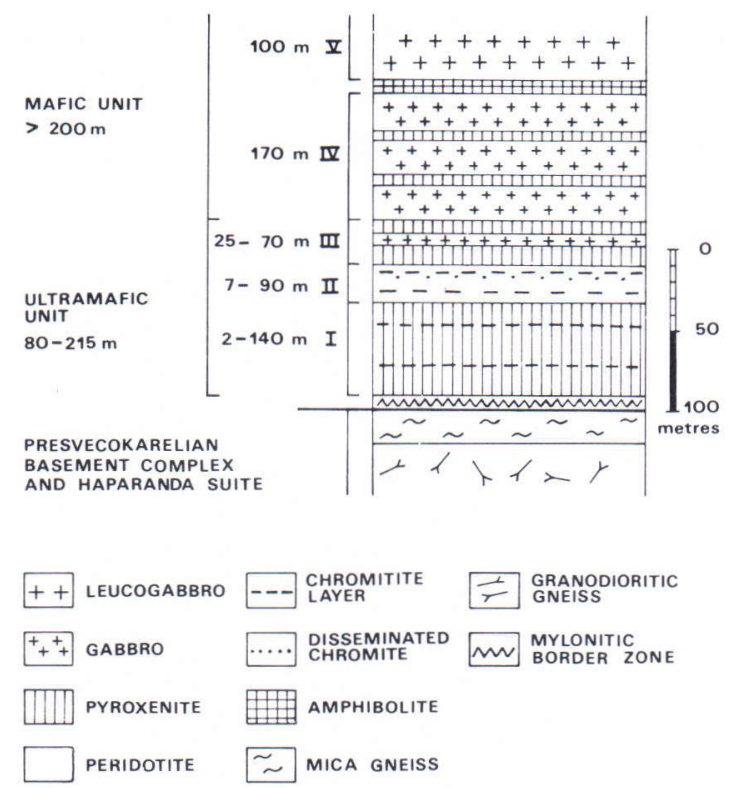

Fig. 2. Schematic and simplified stratigraphy of the Tornio layered intrusion.

the rock types. Rhythmic layering occurs when the peridotite and pyroxenite, and pyroxenite and gabbro alternate. The gabbros also exhibit rhythmic layering within the layers, owing to the alternation of amphibolepredominant and plagioclase-predominant bands a few centimetres thick. Similar rhythmic layering has also been described from the gabbros of the Penikat (Kujanpää 1964) and Stillwater (Hess 1960) layered intrusions.

At the base of the Tornio layered intrusion there is invariably a mylonitized border zone, a few metres thick, composed of tremolite, talc, plagioclase and carbonate. The border zone generally exhibits a weak to moderate chromite dissemination; in one drill intersection even two narrow chromitite layers were observed. The border zone is overlain by the lower pyroxenite layer (I), which has narrow peridotite intercalations and disseminated chromite. The contact with the underlying pyroxenite layer is fairly sharp.

Layer III, like layer I is composed of pyroxenite with gabbroic intercalations. The basic- ity of this layer increases downwards and the layer grades into peridotite. Upwards the layer grades, possibly through norite, into gabbro. The lower layer (IV) of the upper mafic unit is composed of gabbro with pyroxenitic and noritic intercalations. The uppermost known layer (V) is of leucogabbro. Between layers IV and $\mathrm{V}$ a narrow amphibolite layer or silicic sediment fragments are encountered that seem to derive from the collapsed roof of the magma chamber.

The Tornio layered intrusion resembles the Penikat layered intrusion in internal stratigraphy and position. The layered intrusions at Kemi and Penikat are, however, clearly thicker than the intrusion at Tornio (Fig. 1). The Tornio and Kemi intrusions both have ultramafic and mafic rocks in about the same proportions, whereas in the Penikat intrusion the proportion of the ultramafics is distinctly lower (Kujanpää 1964). In the Tornio and Penikat (Kujanpää 1964) intrusions pyroxenites predominate over peridotites, whereas in the Kemi intrusion the reverse is true (Kujanpää 1980). The Stillwater intrusion bears a very strong structural resemblence to the Penikat intrusion (Kujanpää 1964). The sequence of the ultramafic rocks in the Stillwater intrusion (Hess 1960), however, is inverted compared to that in the Tornio and $\mathrm{Pe}$ nikat layered intrusions. The upper pyroxenite layer (III) of the Tornio layered intrusion corresponds to the norite zones at Stillwater and Penikat.

As a rule the rocks of the Tornio layered intrusion are intensely altered and the classification of the rock types was based on examination of thin sections and XRF analyses as well as on core logging. In the peridotites olivine is almost completely altered into serpentine. The rock is mottled and contains magnetite in such abundance that layer II can be traced on magnetic maps. The orthorhombic and monoclinic pyroxenes are altered into uralite, anthophyllite, talc and 
The Tornio layered intrusion - a recently discovered intrusion...

$\mathrm{SiO}_{2}, \mathrm{Fe}, \mathrm{Al}_{2} \mathrm{O}_{3}$

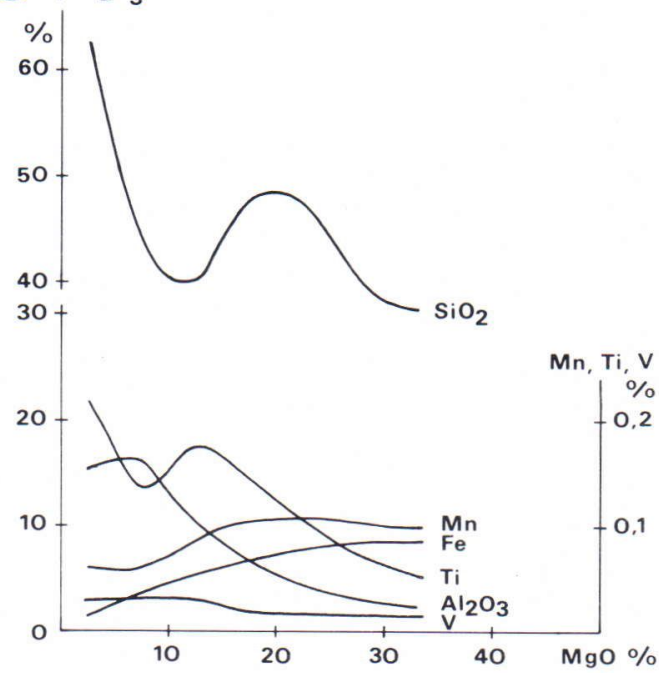

Fig. 3. Geometric means of $\mathrm{SiO}_{2}, \mathrm{Fe}, \mathrm{Al}_{2} \mathrm{O}_{3}, \mathrm{Mn}$, $\mathrm{Ti}$ and $\mathrm{V}$ versus $\mathrm{MgO}$ in the Tornio layered intrusion. chlorite. In places the pyroxenite is composed almost entirely of various amphiboles. The leucogabbro is a pale rock rich in plagioclase that often occurs as phenocrysts.

The rocks of the layered intrusions were analysed for $\mathrm{Cr}_{2} \mathrm{O}_{3}, \mathrm{FeO}_{\mathrm{tot}}, \mathrm{Al}_{2} \mathrm{O}_{3}, \mathrm{MgO}$, $\mathrm{SiO}_{2}, \mathrm{Mn}, \mathrm{V}$ and $\mathrm{Ti}$ (a total of $245 \mathrm{XRF}$ analyses) at the laboratory of the Outokumpu Oy Tornio Works. The geometric means of $\mathrm{SiO}_{2}$, $\mathrm{Fe}, \mathrm{Al}_{2} \mathrm{O}_{3}, \mathrm{Mn}$, Ti and $\mathrm{V}$ calculated from the analyses are plotted as a function of $\mathrm{MgO}$ in Fig. 3. A portion of the gabbro zone was not submitted to analysis and so the results are slightly distorted. The general trend is fairly normal: with the increase in $\mathrm{MgO}$ the contents of $\mathrm{SiO}_{2}, \mathrm{Al}_{2} \mathrm{O}_{3}$ and $\mathrm{Ti}$ decrease, those of $\mathrm{Fe}$ and $\mathrm{Mn}$ increase, and that of $\mathrm{V}$ remains almost constant.

Fig. 4 illustrates how the chemical composition of the rocks varies in a profile from

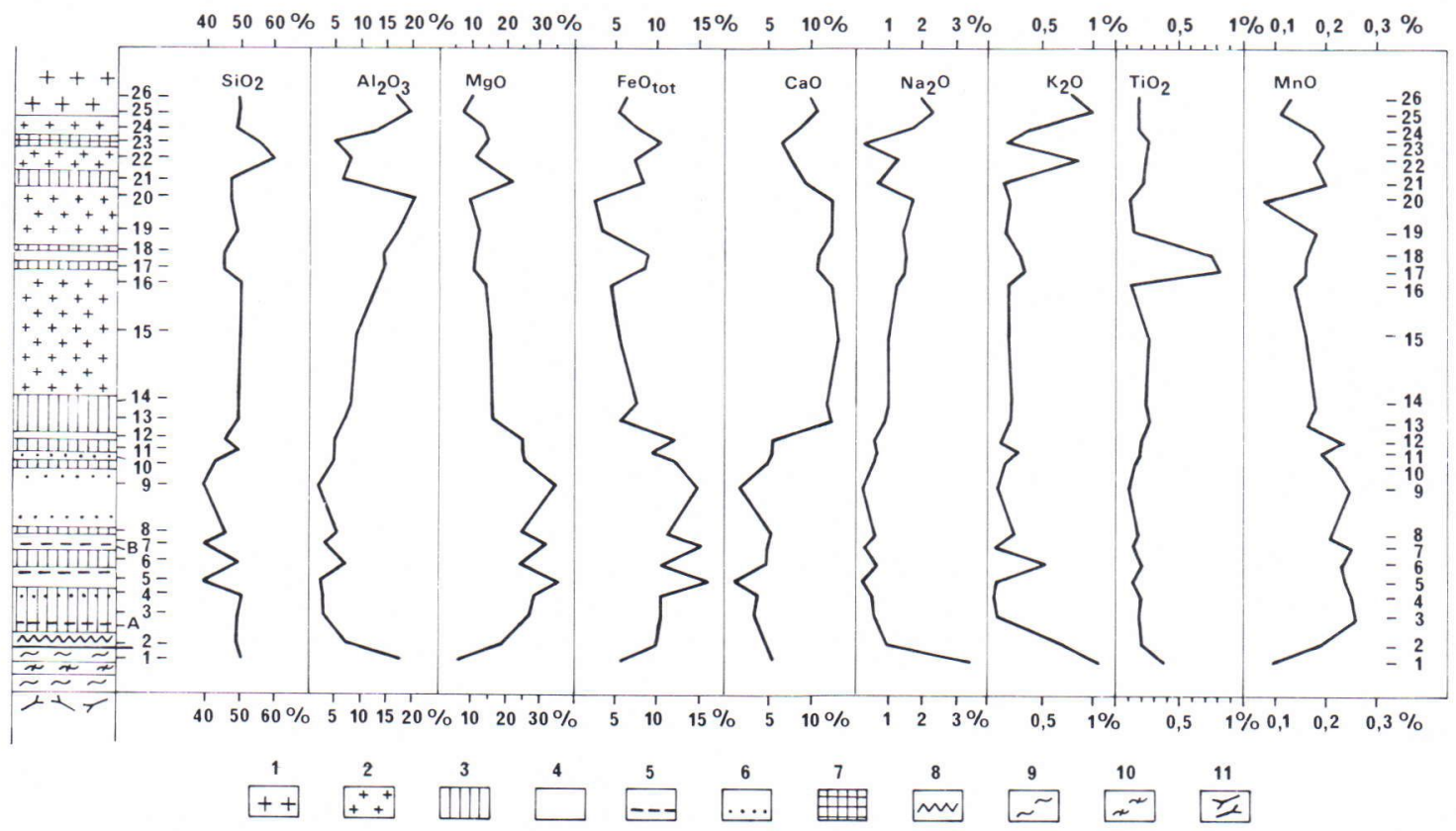

Fig. 4. Graphical presentation of the variations in the chemical composition of the rocks from the base of the intrusion upwards. The zig-zag behavior of the curves is due to rhythmic layering. (XRF analyses, drill holes TO-6, 7 and 8.) 1. leucogabbro 2. gabbro 3. pyroxenite 4. peridotite 5 . chromitite layer 6 . disseminated chromite 7. amphibolite 8 . mylonitic border zone 9. mica gneiss 10 . hornblende gneiss 11. granodioritic gneiss $(9,10$ and $11=$ Presvecokarelian basement complex). 
Table 1. Partial XRF analyses of the main rock types of the Tornio layered intrusion. Numbers refer to Fig. 4 and show the stratigraphic position of the analysed rocks.

\begin{tabular}{lccccccccccccc}
\hline & 2 & 5 & 9 & 3 & 6 & 16 & 19 & 25 & 26 & 23 & $\mathrm{~A}$ & $\mathrm{~B}$ & $\mathrm{C}$ \\
\hline $\mathrm{SiO}_{2}$ & 48.9 & 39.1 & 39.0 & 49.4 & 48.9 & 48.8 & 47.9 & 48.9 & 48.5 & 55.0 & 13.1 & 17.9 & 8.6 \\
$\mathrm{TiO}_{2}$ & 0.22 & 0.14 & 0.12 & 0.19 & 0.22 & 0.20 & 0.14 & 0.17 & 0.17 & 0.26 & 0.66 & 0.64 & 0.45 \\
$\mathrm{Al}_{2} \mathrm{O}_{3}$ & 7.6 & 2.6 & 2.2 & 3.1 & 5.5 & 13.4 & 17.9 & 20.0 & 17.0 & 5.6 & 13.4 & 13.1 & 14.1 \\
$\mathrm{Cr}_{2} \mathrm{O}_{3}$ & 0.82 & 1.06 & 0.79 & 2.21 & 0.68 & 0.36 & 0.16 & 0.16 & 0.25 & 0.19 & 32.2 & 29.4 & 30.4 \\
$\mathrm{FeO}_{\text {tot }}$ ) & 9.6 & 15.9 & 14.8 & 11.2 & 10.7 & 4.4 & 3.1 & 5.3 & 6.2 & 11.1 & 26.2 & 21.6 & 26.6 \\
$\mathrm{MnO}$ & 0.20 & 0.24 & 0.25 & 0.26 & 0.23 & 0.14 & 0.11 & 0.11 & 0.13 & 0.20 & 0.32 & 0.28 & 0.33 \\
$\mathrm{MgO}$ & 19.6 & 35.7 & 35.1 & 27.4 & 24.5 & 13.6 & 11.5 & 7.2 & 10.1 & 15.3 & 9.5 & 11.2 & 14.0 \\
$\mathrm{CaO}$ & 5.0 & 1.2 & 2.1 & 3.6 & 5.0 & 12.6 & 12.8 & 11.5 & 10.3 & 6.8 & 0.4 & 2.1 & 0.2 \\
$\mathrm{Na}_{2} \mathrm{O}$ & 1.0 & 0.2 & 0.2 & 0.5 & 0.7 & 1.2 & 1.4 & 2.3 & 1.9 & 0.3 & n.d. & n.d. & n.d. \\
$\mathrm{K}_{2} \mathrm{O}$ & 0.7 & 0.1 & 0.1 & 0.1 & 0.6 & 0.2 & 0.1 & 1.0 & 0.8 & 0.2 & n.d. & n.d. & n.d. \\
$\mathrm{P}_{2} \mathrm{O}_{5}$ & 0.03 & 0.01 & 0.01 & 0.01 & 0.01 & 0.08 & 0.08 & 0.07 & 0.06 & 0.04 & n.d. & n.d. & n.d. \\
$\mathrm{V}_{2} \mathrm{O}_{5}$ & n.d. & n.d. & n.d. & n.d. & n.d. & n.d. & n.d. & n.d. & n.d. & n.d. & 0.41 & 0.34 & 0.30 \\
$\mathrm{~L} \mathrm{O} . \mathrm{I}$. & n.d. & n.d. & n.d. & n.d. & n.d. & n.d. & n.d. & 1.35 & 2.51 & n.d. & n.d. & n.d. & n.d. \\
\hline Total & 93.67 & 96.25 & 94.67 & 97.97 & 97.04 & 94.98 & 95.19 & 98.06 & 97.92 & 94.99 & 96.19 & 96.56 & 94.98 \\
\hline
\end{tabular}

* Total $\mathrm{Fe}$ as $\mathrm{FeO}$ n.d. $=$ not determined
2. Mylonitic contact zone
5. Peridotite
9. Peridotite
3. Pyroxenite, well preserved
6. Pyroxenite

the base of the layered intrusion upwards. Listed in Table 1 are the chemical compositions of the main rock types of the layered intrusion. The numbers in the table refer to Fig. 4 and show the location of the rock types analysed.

\section{The chromitite horizons}

The chromitite horizons of the Tornio layered intrusion are all in the lower ultramafic unit. Chromite is most abundant in those places where the ultramafic portion is thickest, the very largest amounts being in peridotites (layer II), although chromite is also encountered in the lowermost pyroxenite layer (I) and in the border zone. Chromite occurs as dissemination and layers, a few centimetres to decimetres thick, that show sharp contacts with the adjacent rocks. In

\begin{abstract}
A. Chromitite layer, $27 \mathrm{~cm}$, in pyroxenite, $16 \mathrm{~m}$ from the base of the intrusion.

B. Chromitite layer, $37 \mathrm{~cm}$, in pyroxenite, $65 \mathrm{~m}$ from the base of the intrusion.

C. Chromitite layer, $25 \mathrm{~cm}$, in peridotite, $160 \mathrm{~m}$ from the base of the intrusion. Drill hole TO-2 in another cross-section.
\end{abstract}

one section seven chromitite layers from 3 to $37 \mathrm{~cm}$ thick were intersected. The layers are separated by a distance of a few decimetres to $80 \mathrm{~m}$. The thickest chromitite layers seem to be persistent along the strike. Downwards a layer, 20-30 cm thick, has been traced for over $100 \mathrm{~m}$. Each drill hole that intersected the ultramafic unit also intersected chromitite layers.

The chromitite layers contain 26-32\% $\mathrm{Cr}_{2} \mathrm{O}_{3}$ and their $\mathrm{FeO}_{\text {tot }}$ varies between 22 and $28 \%$. The corresponding averages are $30.3 \%$ $\mathrm{Cr}_{2} \mathrm{O}_{3}$ and $24.9 \% \mathrm{FeO}_{\text {tot }}$ (Table 3). Since the $\mathrm{FeO}_{\text {tot }}$ is so high the $\mathrm{Cr} / \mathrm{Fe}$ ratio of the layers is merely $0.9-1.2$, the average being 1.07 . The contents of $\mathrm{FeO}, \mathrm{V}$, Ti and $\mathrm{Mn}$ in the chromitite layers are higher and that of $\mathrm{SiO}_{2}$ is lower than in the other rock types of the layered intrusion. The $\mathrm{V}_{2} \mathrm{O}_{5}$ content of the chromitite layer fluctuates between 0.23 and $0.41 \%$, 
The Tornio layered intrusion - a recently discovered intrusion...

Table 2. Electron microprobe analyses of altered and homogeneous chromites. (Analysed by S. Uusitalo).

\begin{tabular}{lcccccccccc}
\hline & $\mathrm{N}$, & $\mathrm{Cr}_{2} \mathrm{O}_{3}$ & $\mathrm{FeO}_{\text {tot }}{ }^{*}$ & $\mathrm{Cr} / \mathrm{Fe}$ & $\mathrm{MgO}$ & $\mathrm{Al}_{2} \mathrm{O}_{3}$ & $\mathrm{TiO}_{2}$ & $\mathrm{Ni}$ & $\mathrm{V}_{2} \mathrm{O}_{5}$ & $\mathrm{MnO}$ \\
\hline Homogeneous chromites & 7 & 43.0 & 34.6 & 1.24 & 4.9 & 16.3 & 0.45 & n.d. & n.d. & n.d. \\
Altered chromites: core & 8 & 29.7 & 37.8 & 0.69 & 9.4 & 25.3 & 0.45 & 0.09 & 0.20 & 0.35 \\
\multicolumn{1}{c}{ border } & 8 & 28.6 & 47.8 & 0.53 & 6.1 & 12.0 & 0.70 & 0.20 & 0.29 & 0.63 \\
\hline
\end{tabular}

* Total $\mathrm{Fe}$ as $\mathrm{FeO}$

$\mathrm{N}=$ number of analyses

n.d. $=$ not determined

averaging $0.30 \%$. The PGEs assay 0.1 to $0.3 \mathrm{ppm}$.

The chromitite layers higher up in the peridotite of the layered intrusion differ from those lower down in the pyroxenite by the higher $\mathrm{FeO}$ and $\mathrm{MgO}$, and lower $\mathrm{SiO}_{2}$ and $\mathrm{TiO}_{2}$. Likewise in Penikat (Kujanpää 1964), Kemi (Kouvo 1962), Stillwater (Jackson 1964) and Great Dyke (Metal Bulletin 1981), the upper chromitite horizons are richer in $\mathrm{Fe}$ than are the layers lower down.

The compositions of the chromites were determined at the Metallurgical Research Centre of Outokumpu Oy by a Cameca M.S. 46 electron microprobe. Some of the chromites are homogeneous, others are altered in such a way that the composition of the margins differs from that of the cores. The margins of the altered chromites contain more $\mathrm{FeO}, \mathrm{TiO}_{2}, \mathrm{Ni}, \mathrm{V}_{2} \mathrm{O}_{5}$ and $\mathrm{MnO}$ than do the cores, whereas the cores are richer in $\mathrm{MgO}$ and $\mathrm{Al}_{2} \mathrm{O}_{3}$ than the margins (Table 2). The difference in composition between the cores and the margins can probably be attributed to postmagmatic hydration. The homogeneous chromites are markedly richer in $\mathrm{Cr}_{2} \mathrm{O}_{3}$ than are the altered chromites; further, their $\mathrm{FeO}$ is lower and their $\mathrm{Cr} / \mathrm{Fe}$ ratio higher than those of the latter. The chromites in peridotites show higher $\mathrm{FeO}_{\text {tot }}$ and $\mathrm{MgO}$, and lower $\mathrm{Cr} / \mathrm{Fe}$ and higher $\mathrm{Mg} / \mathrm{Fe}$ than do the chromites in pyroxenites.

\section{Comparison with other chromite deposits}

The Tornio chromite deposit has many of the features that Thayer and Lipin (1978) regard as characteristic of stratiform chromite deposits in contrast to the Alpine type or podiform deposits. Layered intrusions with similar chromitite horizons are the Bird River in Canada (Bateman 1943), Stillwater in U.S.A (Hess 1960, Jackson 1968), Fiskenaesset in Greenland (Ghisler 1976) and Kemi (Kujanpää 1980), Penikat (Kujanpää 1964) and Koitelainen (Mutanen 1979) in Finland. Especially the deposits of Penikat, Bird River and Stillwater resemble the Tornio deposit. In these four the thickness of the chromitites varies from a few centimetres to a few metres. The $\mathrm{Cr}_{2} \mathrm{O}_{3}$ content of the layers fluctuates between 10 and $30 \%$ and their $\mathrm{Cr} / \mathrm{Fe}$ ratio from 0.8 to 1.5. In the layered intrusions of Bushveld in South Africa and of Great Dyke in Zimbabwe, which are estimated to contain $99 \%$ of the world's chromite resources (Thayer and Lipin 1978), the thickness of the chromitite layers varies from 0.1 to $1.8 \mathrm{~m}$. Their $\mathrm{Cr}_{2} \mathrm{O}_{3}$ content, however, is about 44$55 \%$. The $\mathrm{Cr} / \mathrm{Fe}$ ratio of the Bushveld chromium ore is 1.4-2.9: 1 and that of the Great Dyke chromium ore 3.2: 1 (Thayer and Lipin 1978).

In Table 3 the mean compositions and thickness of the chromitite horizons of the Tornio layered intrusion are compared with those of the Kemi, Penikat and Koitelainen intrusions. As mentioned above, the Tornio layered intrusion resembles the Penikat layered intrusion in position and structure. The $\mathrm{FeO}_{\text {tot }}$ and $\mathrm{MgO}$ of the chromitite layers 
Tablc 3. The average chemical composition and thickness of the chromitite horizons in the Tornio layered intrusion compared with those in the Kemi, Penikat and Koitelainen layered intrusions.

\begin{tabular}{lcccccccc}
\hline Deposit & $\mathrm{Cr}_{2} \mathrm{O}_{3}$ & $\mathrm{FeO}_{\text {tot }}{ }^{*}$ & $\mathrm{Cr} / \mathrm{Fe}$ & $\mathrm{Al}_{2} \mathrm{O}_{3}$ & $\mathrm{MgO}$ & $\mathrm{SiO}_{2}$ & $\mathrm{~V}_{2} \mathrm{O}_{5}$ & $\begin{array}{c}\text { Thickness of } \\
\text { horizon m }\end{array}$ \\
\hline Tornio $^{1}$ & 30.3 & 24.9 & 1.07 & 13.4 & 11.1 & 12.6 & 0.30 & $0.1-0.4$ \\
Kemi $^{2}$ & 26.9 & 15.4 & 1.54 & 9.5 & 19.5 & 18.5 & $<0.2$ & $30-90$ \\
Penikat $^{3}$ & 22.9 & 24.9 & 0.81 & $10-13$ & $9-12$ & $24-29$ & n.d. & $0.2-2.5$ \\
Koitelainen $^{4}$ & 20.2 & 27.2 & 0.7 & 12.8 & 4.7 & $23-24$ & 0.64 & 1.3 \\
\hline
\end{tabular}

* Total Fe as $\mathrm{FeO}$

n.d. $=$ not determined

1 Tornio: Söderholm (1980) (5 chromitite layers)

2 Kemi: Kujanpää (1980) (All the chromium ores with a cut-off grade of $20 \% \mathrm{Cr}_{2} \mathrm{O}_{3}$ )

3 Penikat: Kujanpää (1964), Kouvo (1962) (4 chromitite layers)

4 Koitelainen: Mutanen (1979) (Upper chromitite layer)

Table 4. The average compositions of chromites from the Tornio intrusion, the Kemi chromium ore, the Kemi chromitite horizons above the ore, the Penikat, Koitelainen, Bird River, Stillwater and Fiskenaesset intrusions.

\begin{tabular}{lccccccc}
\hline Deposit & $\mathrm{Cr}_{2} \mathrm{O}_{3}$ & $\mathrm{FeO}_{\text {tot }}{ }^{*}$ & $\mathrm{Cr} / \mathrm{Fe}$ & $\mathrm{MgO}$ & $\mathrm{Al}_{2} \mathrm{O}_{3}$ & $\mathrm{~V}_{2} \mathrm{O}_{5}$ & $\mathrm{TiO}_{2}$ \\
\hline Tornio $^{1}$ & 43.0 & 34.6 & 1.24 & 4.9 & 16.3 & $0.2-0.4$ & 0.45 \\
Kemi ore $^{2}$ & 47.0 & 27.4 & $\sim 1.5$ & 8.7 & 12.5 & 0.14 & 0.67 \\
Kemi chromitites $^{3}$ & 42.4 & 33.7 & 1.12 & 5.6 & 15.3 & 0.14 & 0.52 \\
Penikat $^{4}$ & 42.1 & 38.3 & 0.97 & 2.5 & 11.9 & 0.16 & 0.63 \\
Koitelainen $^{5}$ & 42.5 & 40.5 & 0.93 & 0.5 & 9.5 & 1.12 & 3.50 \\
Bird River $^{6}$ & 41.3 & 36.8 & 1.0 & 5.4 & 12.3 & n.d. & 1.08 \\
Stillwater $^{7}$ & 42.9 & 26.8 & 1.47 & 10.2 & 17.6 & 0.07 & 0.58 \\
Fiskenaesset $^{8}$ & 35.1 & 41.4 & 0.78 & 3.5 & 18.6 & 0.40 & 0.75 \\
\hline
\end{tabular}

* Total $\mathrm{Fe}$ as $\mathrm{FeO}$

n.d. $=$ not determined

1 Tornio: Inkinen (1979) Electron microprobe analyses, only homogeneous chromites

2 Kemi ore: Kouvo (1962) Cleaned chromite concentrates, 25 samples from the Elijärvi ore

3 Kemi chromitites: Kouvo (1962) Cleaned chromite concentrates from 7 chromitite horizons $2.5-300 \mathrm{~cm}$ thick 5-20 $\mathrm{m}$ above the Elijärvi chromium ore

4 Penikat: Kujanpää (1964) Cleaned chromite concentrates, 6 samples

5 Koitelainen: Mutanen (1979) Electron microprobe analyses

6 Bird River: Bateman (1945) Cleaned chromite concentrates

7 Stillwater: Howland (1955), Jackson (1968) Cleaned chromite concentrates

8 Fiskenaesset: Ghisler (1976) Electron microprobe analyses

of these deposits are also fairly similar. The $\mathrm{Cr}_{2} \mathrm{O}_{3}$ of the chromitite horizons at Tornio is as high as it is in the Kemi chromium ore and higher than it is in the chromitite layers of Penikat and Koitelainen. The chromitite layers in Tornio have a higher $\mathrm{Cr} / \mathrm{Fe}$ ratio than do the chromitite layers in Penikat and Koitelainen but a markedly lower one than that in the Kemi chromium ore. The $\mathrm{Al}_{2} \mathrm{O}_{3}$ content is about the same in the chromitite layers of Penikat, Koitelainen and Tornio. The chromitite horizons of Tornio, particularly those higher in the deposit, are poorer in $\mathrm{SiO}_{2}$ than are the other Finnish chromite deposits listed in Table 3.

In Table 4 a comparison is made between the average compositions of the chromites from the Tornio layered intrusion and those 
from the Kemi, Elijärvi ore, and the overlying chromitite layers and chromites from Penikat, Koitelainen, Bird River, Stillwater and Fiskenaesset. Since some of the analyses were done on concentrates and some are electron microprobe determinations the results are not directly comparable.

The table shows that the chromites in the chromitite layers overlying the Elijärvi ore are very similar to the Tornio chromites in composition. The chromites of Bird River and Penikat also resemble the Tornio chromites, whereas the chromites of Koitelainen, Fiskenaesset and Kemi chromium ore differ clearly from the Tornio chromites.

\section{Summary and Discussion}

Studies undertaken in the environment of Tornio have modified the general geological picture of the Peräpohja schist area. In addition to the already well-known Kemi and Penikat layered intrusions a third layered intrusion was detected northeast of Tornio. The Tornio layered intrusion resembles the Penikat intrusion in stratigraphic position, chemical composition and position of the chromitites and composition of the chromite. The layered intrusions at Tornio, Kemi and Penikat all have a similar stratigraphic position between the Presvecokarelian basement complex and the Peräpohja schists. In all likelihood the Tornio layered intrusion is of the same age as those of Kemi, Penikat and Koitelainen, i.e. about $2440 \mathrm{Ma}$.

The supracrustal rocks southwest of the Tornio layered intrusion presumably belong to the Presvecokarelian basement complex. The plutonites of the Haparanda suite, or at least some of them, may represent remo- bilised basement complex. The supracrustal rocks that underlie and overlie the layered intrusions are older than them. More age determinations are needed, however, to clarify the age relations between the rock types.

The layered intrusions at Tornio, Kemi and Penikat have stratiform chromite deposits in their ultramafic basal portions. The Kemi intrusion hosts large chromium ores, whereas the chromitite horizons at Tornio and Penikat are narrow. In composition the chromites of Tornio resemble the chromites of the chromitite layers above the Kemi chromium ore and the Penikat chromites. The chromites of the chromitite layers at Tornio and Penikat are rich in $\mathrm{Fe}$ and poor in $\mathrm{Mg}$, and their $\mathrm{Cr} / \mathrm{Fe}$ ratio is low. In addition to chromite occurrences, layered intrusions of this type may also contain PGE, $\mathrm{Ni}, \mathrm{V}, \mathrm{Cu}, \mathrm{Co}$ and $\mathrm{Au}$ mineralisations and ore deposits, as do, for example, the intrusions of Bushveld, Stillwater and Great Dyke. These mineralisations also deserve due consideration in the follow-up studies on the Peräpohja layered intrusions.

Acknowledgements. The authors are indebted to Outokumpu Oy for permission to publish the present paper. Some of the XRF analyses were carried out at the Outokumpu Oy Tornio Works, some at the Geological Laboratory of the Exploration and the electron microprobe analyses were made by Mr. S. Uusitalo at the Pori Works. The maps and diagrams were drawn by Miss Leena Komulainen, the manuscript was translated by Mrs. Gillian Häkli and it was typed by Miss Kirsti Törmänen. Dr. T. A. Häkli and J. Kujanpää, lic. phil. critically read the manuscript.

We express our cordial thanks to all the above people for their help. 


\section{References}

Alapieti, T., 1982. The Koillismaa layered igneous complex, Finland - its structure, mineralogy and geochemistry, with emphasis on the distribution of chromium. Geol. Surv. Finland, Bull. 319. 116 p.

Bateman, J.D., 1943. Bird River chromite deposits, Manitoba. Trans, Canad. Inst. Mining and Metall. 46, 154-183.

Bateman, J. D., 1945. Composition of the Bird River chromite, Manitoba. Amer. Mineral. 30, 596-600.

Brotzen, O., 1973. Rb-Sr dating and microclinization in dioritic rocks of the Haparanda group, northern Sweden. Geol. Fören. Stockholm Förh. 95, 19-24.

Ghisler, M., 1976. The geology, mineralogy and geochemistry of the pre-orogenic Archean stratiform chromite deposits at Fiskenaesset, West Greenland. Monograph series on Mineral Deposits, 14, $156 \mathrm{p}$.

GTL, 1977. Geological Survey of Finland. Annual report on the activities for the year 1976 (In Finnish with an English summary, 75 p.

GTL, 1981. Geological Survey of Finland. Kertomus toiminnasta vuonna 1980, $40 \mathrm{p}$.

Hess, H. H., 1960. Stillwater Igneus Complex, Montana. Geol. Soc. America, Memoir 80, 230 p.

Howland, A. L., 1955. Chromite deposits in central part Stillwater Complex, Sweet Grass County, Montana. U.S. Geol. Surv. Bull. 1015-D, 99-119.

Inkinen, O., 1979. Väliraportti Tornion ympäristön kromiittitutkimuksista. Rep. 001/2542/OI/1979. Outokumpu Oy Malminetsintä, Rovaniemi., 13 p. (in Finnish).

Jackson, E. D., 1968. The chromite deposits of the Stillwater Complex, Montana. In: Ridge, J. D. (ed.): Ore deposits of the United States, 19331967, vol II, 1495-1510.

Kouvo, O., 1962. Havaintoja Kemin malmista. Rep. 19. 2. 62/Outokumpu Oy Kemin kaivos, 8 p. (in Finnish).

Kouvo, O., 1977. The use of mafic pegmatoids in geochronometry. Abs. 5th. Europ. Coll. Geochrom, Pisa, Italy.

Kujanpää, J., 1964. Kemin Penikkain jakson rakenteesta ja kromiiteista. Unpublished thesis. The University of Oulu, 118 p. (in Finnish).
Kujanpää, J., 1980. Geology of the Kemi chromite deposit. In Häkli, T. A. (ed.) Precambrian ores of Finland. Guide to excursions $078 \mathrm{~A}+\mathrm{C}$, Part 2 (Finland). Geol. Surv. Finland, Bull. 1980, 6-13. Manhes, G., Allégre, C. J., Dupré, B. and Hamelin, $B ., 1980$. Lead isotope study of basic-ultrabasic layered complexes: speculation about the age of the Earth and primitive mantle characteristics. Earth Planet. Sci. Lett. 47, 370-382.

Metal Bulletin Monthly, 1981. May, 23-25.

Mutanen, T., 1979. Vanadiini- ja kromi-platinamalmitutkimukset Koitelaisvosien alueella Sodankylässä vuosina 1973-1978. Rep. M19/874279/1/10. Geological Survey of Finland, Rovaniemi, 130 p. (in Finnish).

Patchett, P. J., Kouvo, O., Hedge, C. E. and Tatsumoto, M. (In press) Evolution of continental crust and mantle heterogeneity - evidence from $\mathrm{Hf}$ isotopes. Contribution to Mineralogy and Petrology.

Pertunen, V., 1971a. Pre-Quaternary rocks, 2544 Kemi. Geological Map of Finland 1: 100000.

Perttunen, V., 1971b. Pre-Quaternary rocks, 2544 Runkaus. Geological Map of Finland 1: 100000.

Perttunen, V., 1972. Pre-Quaternary rocks, $2542+$ 2524 Karunki. Geological Map of Finland $1: 100000$.

Perttunen, V., 1975. Pre-Quaternary rocks, 2543 Simo. Geological Map of Finland 1: 100000.

Perttunen, V., 1980. Stratigraphy of the Peräpohja schist area. In Silvennoinen, A. (ed.): Jatulian geology in the eastern part of the Baltic shield. Proceedings of a Finnish-Soviet symposium held in Finland 21st-26th August 1979, 139145.

Söderholm, K., 1980. Väliraportti Tornion ympäristön kromiittitutkimuksista. Outokumpu Oy Kemi mine, 21 p. (in Finnish).

Thayer, T. and Lipin, B., 1978. A geological analysis of world chromite production to the year 2000 A.D. Reprint from Council of Economics of A.I.M.E. Proceedings, 107th Annual Meeting, 1978, 143-146

Welin, E., Christiansson, K. and Nilsson, Ö., 1970. $\mathrm{Rb}-\mathrm{Sr}$ age dating of intrusive rocks of the Haparanda suite. Geol. Fören. Stockholm Förh. $92,336-346$.

Manuscript received, December 11, 1981 